\title{
Moulting and Seasonal Pelage Variations in the Raccoon Dog
}

\author{
Hannu KORHONEN, Mikko HARRI \& Juha ASIKAINEN
}

\begin{abstract}
Korhonen H., Harri M. \& Asikainen J., 1984: Muulting and seasonal pelage variations in the raccoon dog. Acta theriol., 29, 7: 77-88 [With 2 Tables \& 7 Figs.]

An examination was made of the moult and seasonal pelage variations in adult and juvenile raccoon dogs, Nyctereutes procyonoides (Gray, 1834) from Eastern Finland. The Arctic fox (Alopex lagopus) served as a reference animal. Raccoon dog pelage is composed of four types of hairs: guard hairs, long pile hairs, short pile hairs, and underfur. Whelps moult at the age of $4-5$ weeks to a new summer pelage. Growth of dense winter pelage takes mainly place during September, October, and November. The dense winter pelage is maintained until late March. The dense underfur is replaced by a thinner summer one by mid-June. Timing of guard hair moult is rather individual. Total and underfur hair weights on the back and abdomen remain fairly constant during June-August, but increase as winter pelage developes. Shortest guard hair and underfur lengths are found in summer. Skin thickness is highest in summer. Total and skin weights of blue (Arctic) foxes and raccoon dogs in winter are about the same order of magnitude. Length of guard hair and underfur is shorter in the blue fox, especially on the back. Total weight of the raccoon dog winter pelage is highest on the back and tends to be lower on sides and abdomen. Considerable site-specific variations were found in different pelage parameters. Good correlations between hair length and weight and skin weight and thickness were found.

[Dept. of A pplied Zoology, University of Kuopio, POB 138, SF-70101 Kuopio 10, Finland]
\end{abstract}

\section{INTRODUCTION}

Adaptation to seasonal thermoregulatory demands in many mammals includes modification of fur insulation (Hart, 1956). Several Arctic and temperate species are seasonally dimorphic with winter pelages having better insulative values than summer ones (c.f. Hart, 1956; Underwood \& Reynolds, 1980). These seasonal pelage changes have been shown to be photoperiodically controlled (c.f. Bissonette \& Wilson, 1939; Hammond, 1954; Rust et al., 1962; Underwood \& Reynolds, 1980); decreasing day length in autumn initiates a change towards a dense winter pelage while increasing day length in spring leads to a thinner summer pelage. A thicker winter pelage affects heat losi reducing heat transfer from the body to the environment (Scholander et al., 1950). Seasonal pelage changes could also influence the metabolic response of the animal to air temperature $\left(\mathrm{T}_{\mathrm{a}}\right)$ (c.f. Irving et al., 1955; Hart et al., 1965; Korhonen et al., 1983a), thus, having an impact on their energetics. 
The raccoon dog (Nyctereutes procyonoides Gray 1834) has attained economical importance in Finnish fur animal production during the last decade (c.f. Farmarens kalender, 1980). Although studies on its energy metabolism (e.g. Mäkelä \& Kiiskinen, 1978, 1979, 1980; Korhonen et al., 1982, 1983b) and its thermoregulatory properties (Korhonen et al., 1983a) have been performed, the knowledge of its basic biology is still scarce. For example, few data are available about its moult cycle and seasonal pelage variations (c.f. Heptner et al., 1974; Asikainen, 1983).

The purpose of this study was to evaluate seasonal pelage differences in growing juvenile and adult raccoon dogs under commercial fur farm conditions. The Arctic (blue) fox (Alopex lagopus), a thick-furred canid with known properties of its pelage and moult served as a "reference animal".

\section{MATERIAL AND METHODS}

Animals used in this study originated from the Koillis-Savon Turkis Ltd fur farm in Juankoski, Eastern Finland. These farmbred animals were reared under typical commercial fur farm conditions. Five groups of raccoon dogs were studied from June through December 1982. Whelps born in the spring constituted 4 groups. The fifth group was adult raccoon dogs. The animals were pelted according to timing illustrated in Table 1.

Table 1

Test animals, numbers, weights, ages and time of pelting.

\begin{tabular}{lllcll}
\hline $\begin{array}{c}\text { Group number, } \\
\text { species }\end{array}$ & M & F & $\begin{array}{c}\text { Weight, } \\
\mathrm{kg}\end{array}$ & $\begin{array}{c}\text { Age, } \\
\text { months }\end{array}$ & $\begin{array}{c}\text { Time of } \\
\text { pelting }\end{array}$ \\
\hline 1 Raccoon dog & 3 & 0 & $1.2-1.5$ & 2 & late June \\
2 Raccoon dog & 2 & 1 & $4.0-6.0$ & 3.5 & mid August \\
3 Raccoon dog & 2 & 2 & $5.1-7.0$ & 5 & end September \\
4 Raccoon dog & 4 & 2 & $7.2-8.6$ & 7 & early December \\
5 Raccoon dog & 3 & 3 & $7.0-9.9$ & 12 & early June \\
6 Blue fox & 4 & 0 & $6.3-7.9$ & 7 & early December \\
\hline
\end{tabular}

Pelt samples were taken from nine locations as shown in Fig. 1 by using a cork borer with a diameter of $19 \mathrm{~mm}$ (c.f. Kaszowski et al., 1970). Skin pieces with hairs were weighed to the nearest $1 \mathrm{mg}$, after which hairs were removed with a scalpel. Guard hair and underfur weighed separately. Length of guard hair and underfur were measured to the nearest $1 \mathrm{~mm}$. Skin thickness was measured with a ROCT 577-68 dial micrometer to the nearest $0.01 \mathrm{~mm}$. Values were calculated per unit surface area, $\mathrm{cm}^{2}$.

Moulting and fur growth patterns were evaluated by visual examination of ten growing juvenile raccoon dogs ( 5 males, 5 females) from birth in late April year-round to the next summer and, similarly, of the adult raccoon dogs (5 males, 5 females) year-round. However, only the main stages of moult cycles were observed. No attempt was made to make a detailed description of individual stages. 
Thermal insulation of adult raccoon dog and blue fox winter pelage was determined by measuring the temperature gradient in the pelage through which a known quantity of heat was flowing. Measurements were made with a hot-plate kept at about $+38^{\circ} \mathrm{C}$ with the outside air at $+18^{\circ} \mathrm{C}$. Measurements were made at wind speeds varying from 0 to $3.5 \mathrm{~m} \cdot \mathrm{s}^{-1}$. For further description of the method see Tregear (1965) and Meinander (1980). The wind was directed from the head of the pelage longitudinally towards the tail.

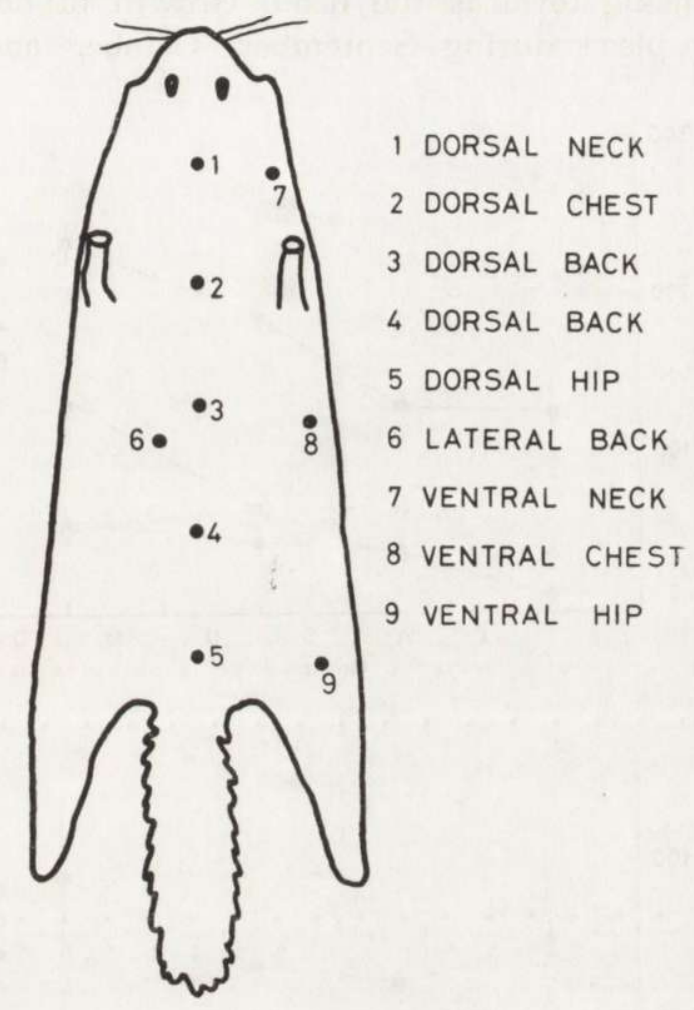

Fig. 1. Sketch of a raccoon dog skin showing different sampling positions.

\section{RESULTS}

The raccoon dog pelage is composed of four types of hairs: (1) guard hairs, (2) long pile hairs, (3) short pile hairs, and (4) underfur or woolly hairs. The guard hair is stiff and straight. The lancet, which is the widest part of the hair, lies $5-25 \mathrm{~mm}$ from the tip of the guard hair. On the dorsal region of the neck, the lancet is wider than on the dorsal region of the hip. Long pile and short pile hairs are intermediate guard hairs. They are shorter and thinner than guard hairs. The short pile hair is shorter than the long pile hair being about the same order of magnitude as underfur. The underfur is short, thin, and wavy.

Raccoon dog whelps are born by the end of April or in May. Whelp 
pelage is short. Whelps moult at the age of $4-5$ weeks a new summer pelage which resembles that of the adults. This summer pelage is composed of stiffer guard hairs than the whelp pelage. The underfur is thin and not dense. The summer moult occurs in juvenile and adult raccoon dogs during the July-October period. The moult begins from the tail advancing towards the head. Growth of dense winter pelage mainly takes place during September, October and November. The
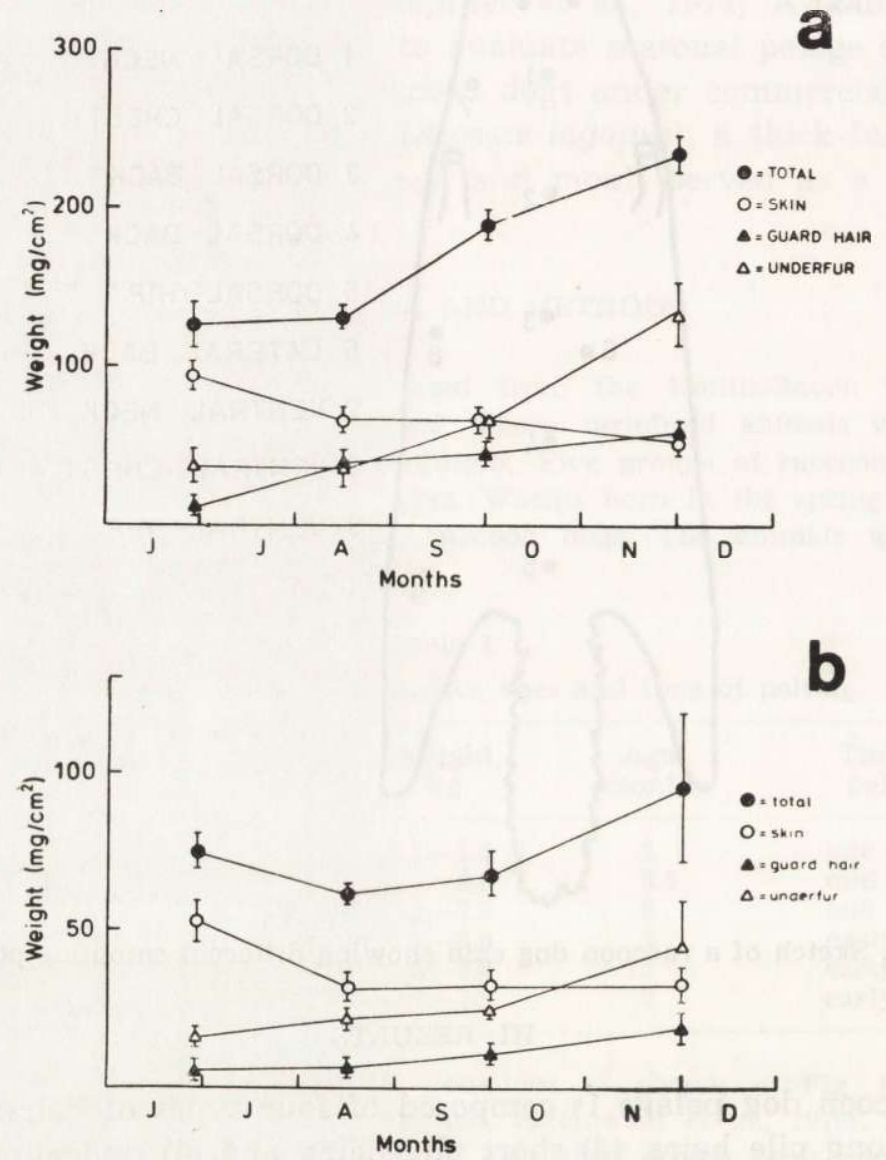

Fig. 2. Total, skin, guard hair and underfur weights of juvenile raccoon dogs during June-December. a: back. b: abdomen.

winter pelage is complete in late November-December when hair growth ceases. The skin is then creamy-white in colour. The winter pelage is maintained until late March. The spring moult begins in April when the dense underfur is shed. The growth of a thinner summer pelage begins from the head advancing towards the tail. The dense winter underfur is replaced by a thinner summer one by mid-June. However, 
the timing of guard hair moult is rather individual but most winter guard hairs are lost by July.

Physical traits of raccoon dog pelts are presented in Figures 2 and 3 , and Table 2. Total and underfur hair weights on the back and abdomen remained fairly constant during June-August. Thereafter, their weights

Table 2

Physical traits of winter pelage of adult raccoon dogs at different sampling positions. The values are expressed as mean $\pm \mathrm{SD}$. Gh: guard hairs. Uf: underfur.

\begin{tabular}{|c|c|c|c|c|c|c|c|}
\hline \multirow{2}{*}{$\begin{array}{l}\text { Region } \\
\text { number }\end{array}$} & \multicolumn{4}{|c|}{ Weight $\left(\mathrm{mg} / \mathrm{cm}^{2}\right)$} & \multicolumn{2}{|c|}{ Hair length $(\mathrm{cm})$} & \multirow{2}{*}{$\begin{array}{c}\text { Skin } \\
\text { thickness } \\
(0.01 \mathrm{~mm})\end{array}$} \\
\hline & Total & Skin & Gh & Uf & $\mathrm{Gh}$ & Uf & \\
\hline 1 & $332 \pm 28$ & $105 \pm 8$ & $75 \pm 13$ & $152 \pm 19$ & $8.2 \pm 0.6$ & $5.2 \pm 0.3$ & $106 \pm 9$ \\
\hline 2 & $216 \pm 32$ & $51 \pm 10$ & $47 \pm 6$ & $118 \pm 28$ & $8.0 \pm 1.0$ & $4.9 \pm 0.3$ & $50 \pm 12$ \\
\hline 3 & $252 \pm 27$ & $55 \pm 3$ & $59 \pm 13$ & $138 \pm 26$ & $9.3 \pm 0.7$ & $5.7 \pm 0.4$ & $59 \pm 3$ \\
\hline 4 & $220 \pm 13$ & $50 \pm 7$ & $55 \pm 10$ & $115 \pm 12$ & $9.4 \pm 0.7$ & $5.8 \pm 0.4$ & $50 \pm 8$ \\
\hline 5 & $256 \pm 33$ & $55 \pm 17$ & $47 \pm 5$ & $154 \pm 23$ & $8.9 \pm 0.7$ & $6.0 \pm 0.4$ & $42 \pm 6$ \\
\hline 6 & $171 \pm 21$ & $46 \pm 4$ & $32 \pm 5$ & $93 \pm 12$ & $8.2 \pm 0.4$ & $5.4 \pm 0.3$ & $47 \pm 5$ \\
\hline 7 & $106 \pm 8$ & $41 \pm 4$ & $23 \pm 2$ & $42 \pm 8$ & $4.6 \pm 0.3$ & $2.9 \pm 0.3$ & $37 \pm 3$ \\
\hline 8 & $57 \pm 12$ & $24 \pm 2$ & $10 \pm 4$ & $23 \pm 7$ & $4.8 \pm 0.7$ & $2.5 \pm 0.3$ & $24 \pm 3$ \\
\hline 9 & $125 \pm 3$ & $35 \pm 6$ & $21 \pm 4$ & $69 \pm 8$ & $5.8 \pm 0.4$ & $3.7 \pm 0.3$ & $34 \pm 5$ \\
\hline
\end{tabular}

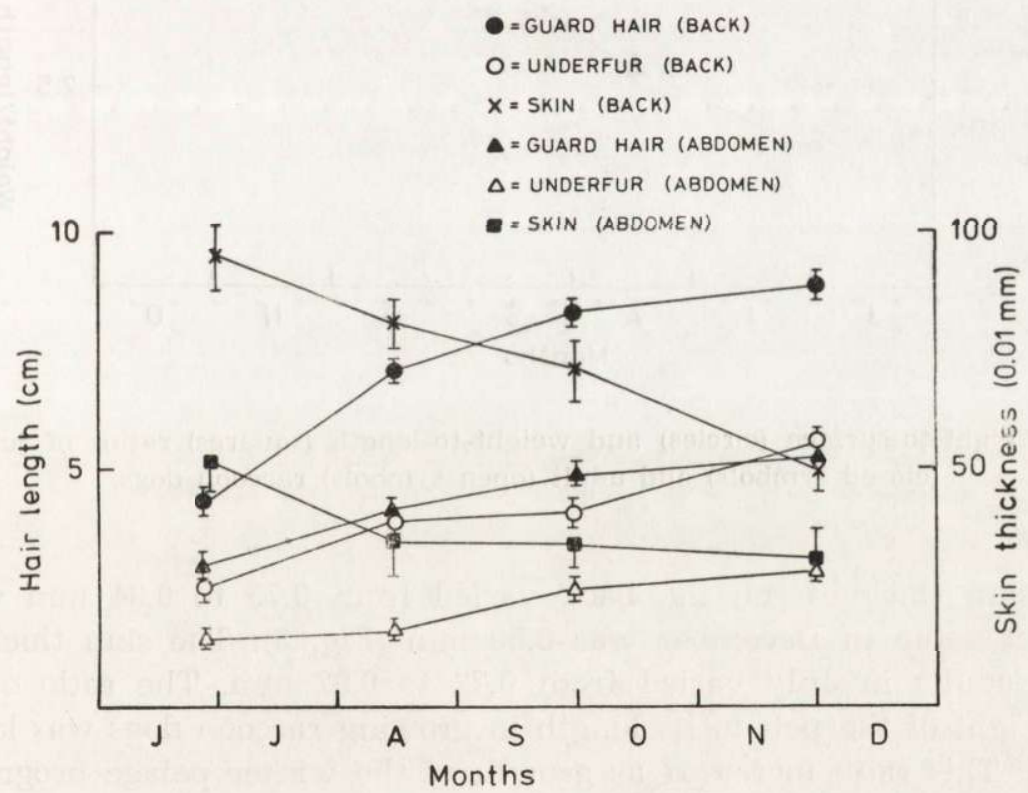

Fig. 3. Hair length and skin thickness of juvenile raccoon dog pelts.

increased as winter pelage developed. Highest values were found in December. Guard hair weights on the back and abdomen tended to increase during autumn. Weights in winter were significantly greater 
than in summer $(p<0.05)$. The skin weights showed an opposite trend; highest values were found in summer, and weights decreased throughout the autumn. Weights in summer were significantly greater than in winter $(p<0.05)$. Shortest guard hair and underfur lengths were found in summer on the back as well as on the abdomen (Fig. 3). Length of guard hairs increased faster during the growing season (June-September) than that of the underfur.

Skin thickness showed a different trend to that of hair length. It was thickest in summer and thinnest in winter. During June-September

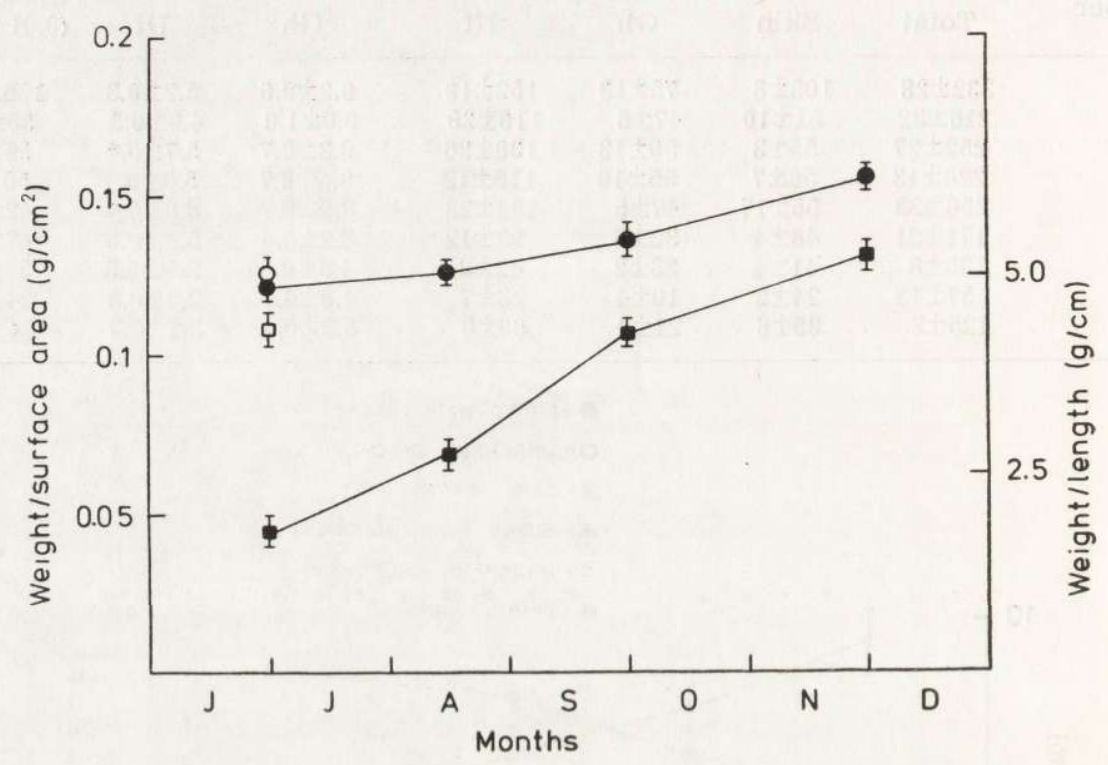

Fig. 4. Weight-to-surface (circles) and weight-to-length (squares) ratios of juvenile (closed symbols) and adult (open symbols) raccoon dogs.

whelp skin thickness on the back varied from 0.75 to $0.94 \mathrm{~mm}$ while a typical value in December was $0.50 \mathrm{~mm}$ (Fig. 3). The skin thickness for the adults in July varied from 0.72 to $0.92 \mathrm{~mm}$. The ratio of the total weight of the pelt to its length in growing raccoon dog 3 was lowest in June. This ratio increased as growth of the winter pelage progressed (Fig. 4). On the other hand, the ratio of the total pelt weight to its surface area did not increase much during the growth phase of the animal. This value was equal for both young whelps with an average body weight of $1.3 \mathrm{~kg}$ and adults in summer pelage with an average weight of about $8 \mathrm{~kg}$. 
Fig. 5 shows the relationship between summer pelage and the winter pelage in adult raccoon dogs. Total weight is lighter in summer than in winter. In addition, weight and length values of guard hair and underfur are lower in summer than in winter. On the other hand, skin weight and thickness values are higher in summer than in winter.

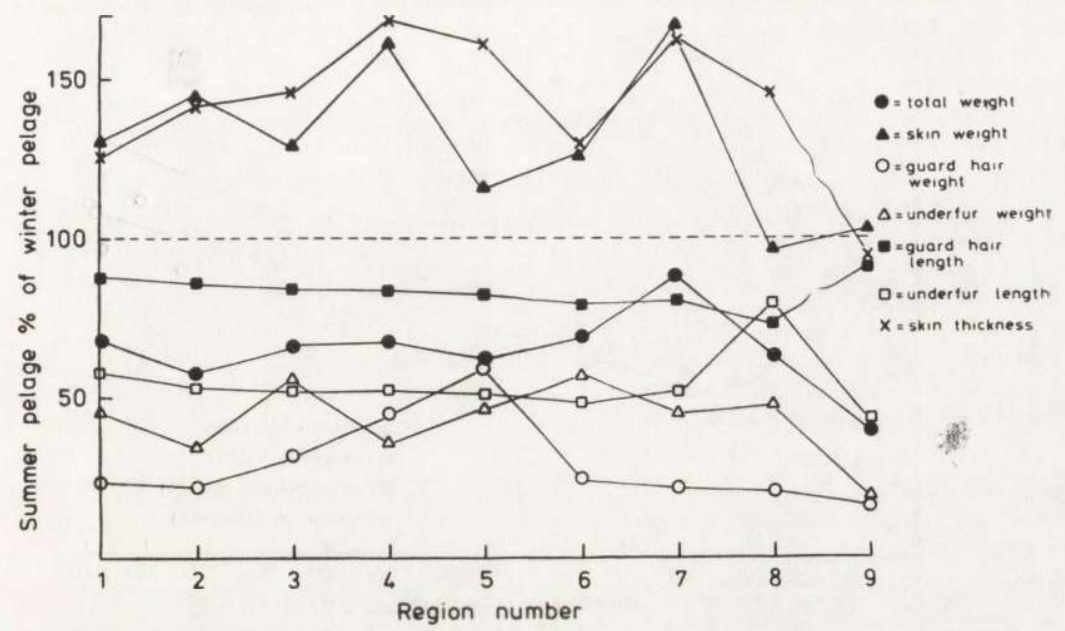

Fig. 5. Summer pelage as a percentage of winter pelage in adult raccoon dogs at different sampling positions.

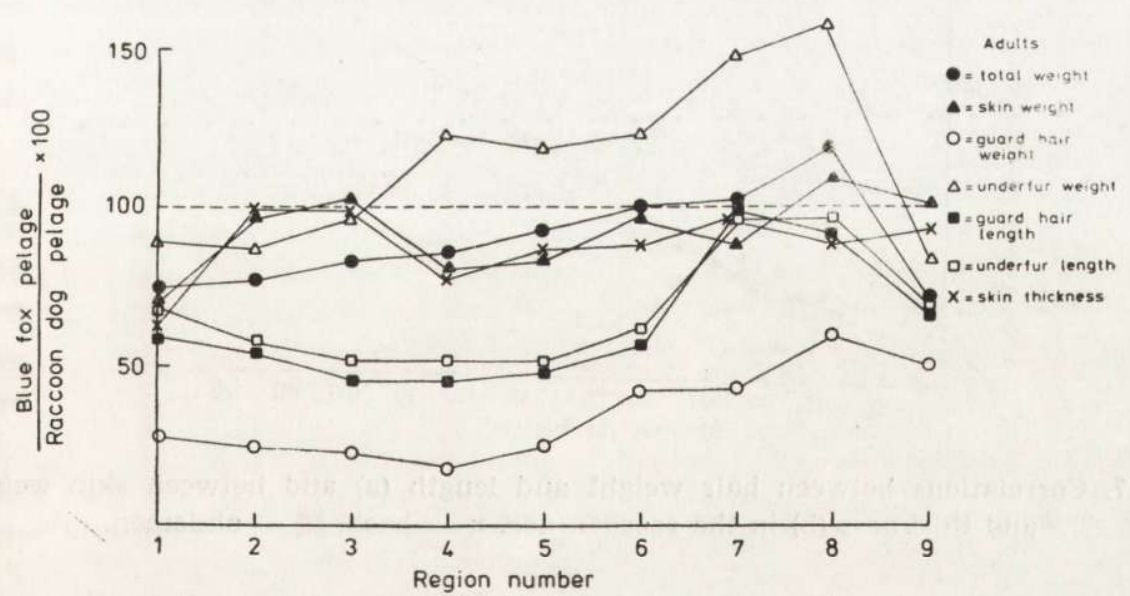

Fig. 6. Blue fox winter pelage as a percentage of raccoon dog winter pelage at different sampling positions.

Total and skin weights of blue fox and raccoon dog winter pelages are about the same order of magnitude (Fig. 6). Skin thickness is also similar. Guard hair and underfur is shorter in the blue fox, especially 
on the back. Corresponding values on the abdomen are comparable to those of the raccoon dog. Guard hair of blue foxes is clearly lighter than that of raccoon dogs while underfur weight in the former tends to be heavier, especially on the sides and abdomen.

The physical traits of the adult raccoon dog winter pelage is shown in Table 2. Total weight of the pelage is highest on the back and tends
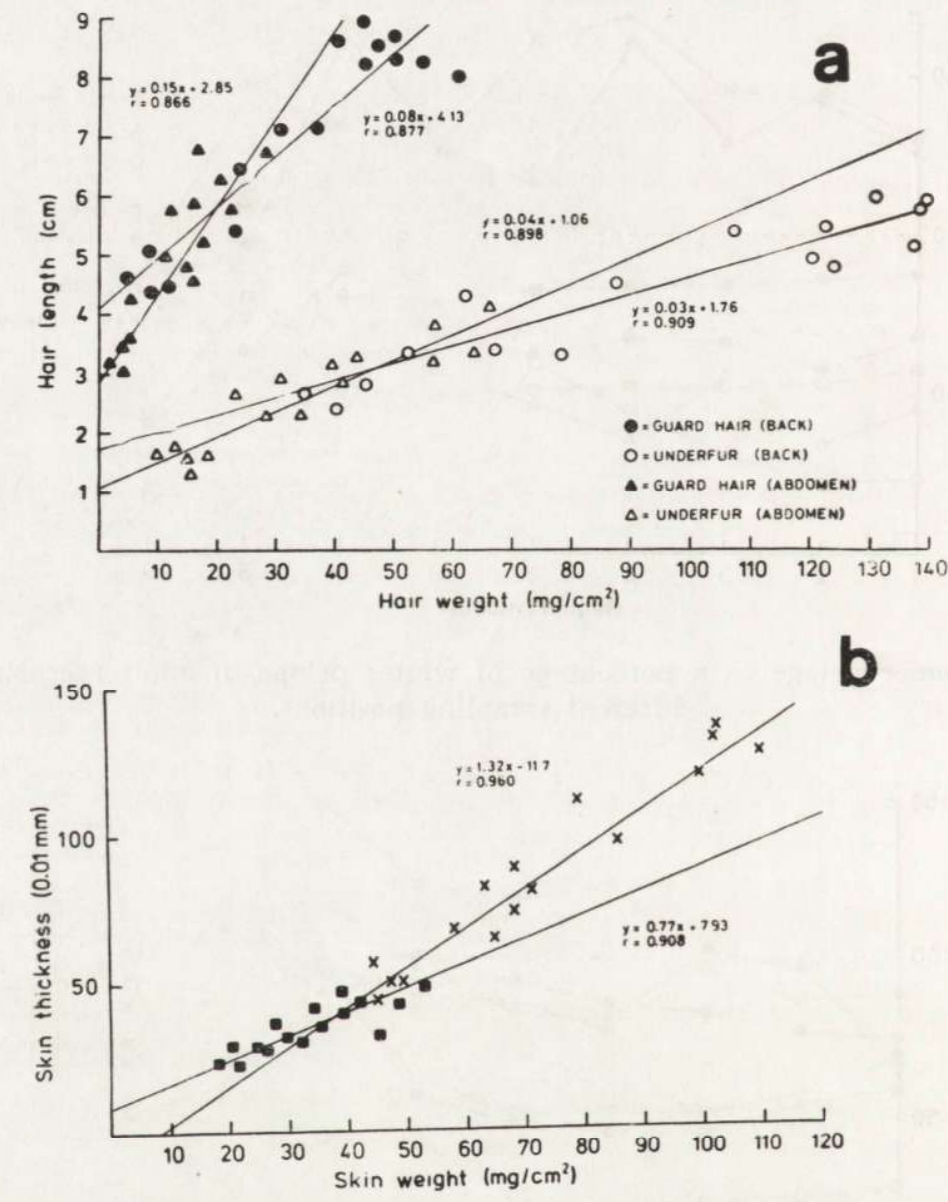

b

Fig. 7. Correlations between hair weight and length (a) and between skin weight and thickness (b) in the raccoon dog. $\mathrm{x}-$ back, $\mathbf{-}$ - abdomen.

to be lower on the sides and abdomen. Other measures show the same tendency. Highest guard hair and underfur lengths were found on dorsal region of the back and the hip. In general, considtrable site-specific variations in different pelage parameters were found. Hair length vs. hair weight as well as skin weight vs. skin thickness correlated well on the back and abdomen (Fig. 7). 
Thermal insulation per unit thickness of raccoon dog and blue fox winter pelages was of the same order of magnitude; insulation values were about 9 Clo. A wind speed of $3.5 \mathrm{~m} \cdot \mathrm{s}^{-1}$ did not cause any changes in the thermal insulation of pelages of these species.

\section{DISCUSSION}

In many species fur length of dried pelts has been found to be inversely related to its insulative quality (Scholander et al., 1950; Hart, 1956). In the Arctic fox, fur length is nearly twice as long in winter as in summer. According to Underwood \& Reynolds (1980) winter values of underfur on the back varies from 4 to $5 \mathrm{~cm}$. These are consistent with our findings. In addition, fur insulation in the Arctic fox has been found to be about $50 \%$ greater in winter than in summer (Scholander et al., 1950). We found that guard hair length of the raccoon dog summer pelage was about $80 \%$ of the corresponding winter value. Summer underfur length, on the other hand, was about half that of winter underfur. According to Hammel (1955), the main factor determining the pelage conductivity is the depth of underfur. Thus, the seasonal change in fur insulation of raccoon dog and Arctic fox is about the same order of magnitude.

Thermal insulation of pelage is highly dependent on the hair density if wind is passing over its surface. The quality criterion for a dense fur is then about 1000 hairs $\cdot \mathrm{cm}^{-2}$ (c.f. Tregear, 1965). Below this hair density, wind easily penetrates deep into the fur. Thermal insulation per unit thickness of the raccoon dog winter pelage resembles that of the blue fox. This was to be expected because the thickness of underfur in both species is about the same order of magnitude. Thermal insulation expressed as Clo units in both species was about 9. Scholander et al., (1950) determined that for the Arctic fox about 8 Clo which is consistent with our findings.

Cooling rates of deceased animals roughly estimate the animal' thermal conductance (c.f. Bakken, 1976; McNab, 1980; Aschoff, 1981). A comparison of cooling constants between winter-furred raccoon dogs and blue foxes showed that there were no conductance differences between these species (Korhonen et al., 1983a; Korhonen \& Harri, 1983). This confirms the idea that body insulation of these species is equivalent.

The total winter pelage weights of both species are similar. However, total pelage weight of the raccoon dog tends to be slightly higher on the back and hips but not on the sides. Although underfur length in the blue fox was shorter, the underfur weight, especially on the hips, sides, and abdomen, was higher than that of the raccoon dog. It seems that the overall body surface of blue fox may be better insulated. Underwood 
\& Reynolds (1980) found that those body sites which are exposed to environment, when the Arctic fox is in curled position, have greater fur lengths in all seasons than the more protected body sites. The importance of the ventral surface as an avenue of conductive heat loss was shown in our earlier paper (Korhonen et al., 1983a). The cooling rate of a raccoon dog lying on an uninsulated surface was double that on a styrofoam mat. In general, however, animals have contact with solid surfaces at only very limited portions of their total surface areas. Thus, in many cases conductive heat transfer may be relatively small (c.f. Christopherson \& Young, 1981).

During growth of the hair, the skin is thicker than during the resting phase (c.f. Bullough \& Laurence, 1958; Hyvärinen et al., 1971). In summer, raccoon dog skin was considerablely thicker and heavier than in winter. This results from hair follicle activity in the summer. The opposite is true in winter when skin weight and thickness decrease. Although the summer pelage is shorter and less dense than the winter one and provides les; thermal insulation, it is not much lighter because the skin is heavier. It should be noted that we measured skin weights from dried pelts. In a live animal, the skin contains water, and although the water percentage could be equal in thin as well as in thick skins, the absolute amount of water is higher in the latter. Thus its weight increases.

Acknowledgements: This work has been financially supported by the Finnish Research Council for Natural Sciences and by the Juankoski Commune. Thanks are due to Mrs. Leila Wenäläinen for her assistance in farming of the experimental animals. The authors wish to acknowledge Professor Jay Huner for kindly correcting the language of the manuscript. Warmest thanks are due to Miss Riitta Tirkkonen and Miss Teija Laitila for skillfull and valuable help throughout this study.

\section{REFERENCES}

1. Aschoff J., 1981: Thermal conductance in mammals and birds: its dependence on body size and circadian phase. Comp. Biochem Physiol. 69A: 611-619.

2. Asikainen J., 1983: Tutkimuksia tarhatun supikoiran karvan laadusta nahkomisaikaan: Karvan pintarakenne turkin laadun ilmentäjänä. Pro gradu tutkielma, Kuopion korkeakoulu.

3. Bakken G. S., 1976: An improved method for determining thermal conductance and equilibrium body temperature with cooling curve experiments. J. Thermal Biol., 1: 169-175.

4. Bissonette T. H. \& Wilson E., 1939: Shortening daylight periods between May 15 and September 12 and the pelt cycle of the mink. Science, 89: 418-419.

5. Bullough W. S. \& Laurence E. B., 1958: The mitotic activity of the follicle. [In: Montagna W., Ellis R. A., eds., "The Biology of Hair Growth"] Academic Press: 65-90. New York.

6. Christopherson R. J. \& Young B. A., 1981: Heat flow between large terrestrial animals and the cold environment. Can. J. Chem. Eng., 59: 181-188. 
7. Farmarens kalender, 1980. Finlands Pälsdjuruppfödares Förbund r.f.

8. Hammel H. T., 1955: Thermal properties of fur. Am. J. Physiol., 182: 369-376.

9. Hammond J., Jr. 1954: Effects of artificial lightning on the reproductive and pelt cycles of mink. W. Heffer \& Sons: 1-16. Cambridge.

10. Hart J. S., 1956: Seasonal changes in insulation of the fur. Can. J. Zool., 34: $53-57$.

11. Hart J. S., Pohl H. \& Tener J. S., 1965: Seasonal acclimatization in varying hare (Lepus americanus). Can. J. Zool., 43: 731-744.

12. Heptner V., Naumov N., Jürgenson J., Sludski A., Cirikova A. \& Bannikov A., 1974: Band II. Seekühe und Raubtiere. [In: Heptner V., Naumov N., eds., "Die Säugetiere der Sovjetunion"]. Gustav Fischer Verlag: 1-1006. Jena.

13. Hyvärinen H., Pelttari A. \& Saure L., 1971: Seasonal changes in the histology and alkaline phosphatase distribution of the skin of the common shrew and of the bank vole as a function of hair cycle. Aquilo. Ser. Zool., 12: 43-52.

14. Irving L., Krog H. \& Monson N., 1955: The metabolism of some Alaskan animals in winter and summer. Physiol. Zool., 28: 173-185.

15. Kaszowski S., Rust C. C. \& Shackelford R. M., 1970: Determination of hair density in the mink. J. Mammal., 51: 27-34.

16. Korhonen H., Harri M. \& Asikainen J., 1982: Effect of various diets and energy levels on the growth of farmed raccoon dogs. Savonia, 5: 1-9.

17. Korhonen H., Harri M. \& Asikainen J., 1983a: Thermoregulation of polecat and raccoon dog: a comparative study with stoat, mink and blue fox. Comp. Biochem. Physiol., 74A: 225-230.

18. Korhonen H., Harri M. \& Asikainen J., 1983b: Energy requirements of growing farm-raised raccoon dogs. Acta Zool. Fenn. (in press).

19. Korhonen H. \& Harri M., 1983: Seasonal changes in thermoregulation of the raccoon dog (Nyctereutes procyonoides Gray 1834). Comp. Biochem. Physiol. (in press).

20. McNab B. N., 1980: On estimating thermal conductance in endotherms. Physiol. Zool., 53: 145-156.

21. Meinander H., 1980: Vaatetusfysiologia-käsitteet ja tärkeimmät tutkimusmenetelmät. VTT Tekstiililaboratorio, Tiedonanto 18: 1-42.

22. Mäkelä J. \& Kiiskinen T., 1978: Supikoiran kasvatus ja ruokinta. Suomen Turkiseläinten Kasvattajain Liitto. (moniste).

23. Mäkelä J. \& Kiiskinen T., 1979: Supikoiran (suomensupin) kasvatus ja ruokinta. Turkistalous, 51: 494-502.

24. Mäkelä J. \& Kiiskinen T., 1980: Supikoiran (suomensupin) kasvatus ja ruokinta. Turkistalous, 52: 368-373.

25. Rust C. C., Shackelford R. M. \& Meyer R. K., 1965: Hormonal control of pelage cycles in the mink. J. Mammal., 46: 549-565.

26. Scholander P. F., Hock R., Walters V. \& Irving L., 1950: Adaptation to cold in Arctic and tropical mammals and birds in relation to body temperature, insulation and basal metabolic rate. Biol. Bull., 99: 259-271.

27. Tregear R. T., 1965: Hair density, wind speed and heat loss in mammals. J. Appl. Physiol., 20: 796-801.

28. Underwood L. S. \& Reynolds P., 1980: Photoperiod and fur lengths in the Arctic fox (Alopex lagopus L.). Int. J. Biometeor., 24: 39-48.

Accepted, July 7, 1983. 
Hannu KORHONEN, Mikko HARRI i Juha ASIKAINEN

LINKA I SEZONOWE ZMIANY SIERSCI U JENOTA

\section{Streszczenie}

Badano przebieg linki i sezonową zmianę uwłosienia u dorosłych i młodych jenotów Nyctereutes procyonoides (Gray, 1834) we wschodniej Finlandii (Ryc. 1). Do porównań użyto podobnych obserwacji robionych na pieśćcu Alopex lagopus (Tabela 1). Sierść jenota składa się z 4 typów włosów: ościstych, długich puchowych, krótkich puchowych i wełnistych. Szczeniaki linieją w wieku 4-5 tygodni uzyskując sierść letnią. Wzrost gęstości sierści zimowej odbywa się głównie w ciągu września, października i listopada (Ryc. 2). Taka gęsta sierść utrzymuje się do marca. Gęste włosy wełniste są zastępowane przez cienkie letnie w okresie do połowy czerwca. Okres wypadania włosów ościstych jest cechą indywidualną. Ciężar całkowity sierści i ciężar włosów wełnistych na grzbiecie i brzuchu był względnie stały $\mathrm{w}$ ciągu czerwca-sierpnia, lecz wzrastał w momencie rozwijania się okrywy zimowej (Ryc. 3). Letnia długość włosów ościstych jest najmniejsza. Grubość skóry jest latem wyższa (Ryc. 5). Ciężar całkowity skóry pieśćca i jenota w zimie jest podobnej wielkości (Tabela 2). Piesiec ma, szczególnie na grzbiecie, nieco krótsze włosy ościste i wełniste (Ryc. 6). Całkowity ciężar zimowej sierści jenota jest wyższy na grzbiecie i ma tendencję do obniżania się na bokach i brzuchu. Stwierdzono dodatnią korelację między długością i ciężarem włosów a ciężarem i grubością skóry (Ryc. 7). 